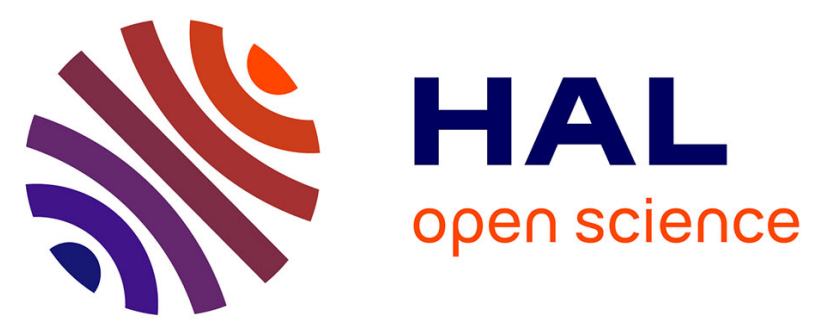

\title{
A Joint Study of Seismicity and SAR Interferometry Observations for Assessing the Possibility of an Eruption of the Dormant Bolshaya Udina Volcano
}

\author{
S. L Senyukov, V. O Mikhailov, I. N Nuzhdina, E. A Kiseleva, S. Ya. Ya
} Droznina, V. A Timofeeva, M. S Volkova, Nikolai M Shapiro, T. Yu. Yu Kozhevnikova, Z. A Nazarova, et al.

\section{To cite this version:}

S. L Senyukov, V. O Mikhailov, I. N Nuzhdina, E. A Kiseleva, S. Ya. Ya Droznina, et al.. A Joint Study of Seismicity and SAR Interferometry Observations for Assessing the Possibility of an Eruption of the Dormant Bolshaya Udina Volcano. Journal of Volcanology and Seismology, 2020, 14 (5), pp.305 - 317. 10.1134/s074204632005005x . hal-03088541

\section{HAL Id: hal-03088541 https://hal.science/hal-03088541}

Submitted on 19 Jul 2021

HAL is a multi-disciplinary open access archive for the deposit and dissemination of scientific research documents, whether they are published or not. The documents may come from teaching and research institutions in France or abroad, or from public or private research centers.
L'archive ouverte pluridisciplinaire HAL, est destinée au dépôt et à la diffusion de documents scientifiques de niveau recherche, publiés ou non, émanant des établissements d'enseignement et de recherche français ou étrangers, des laboratoires publics ou privés. 


\title{
A Joint Study of Seismicity and SAR Interferometry Observations for Assessing the Possibility of an Eruption of the Dormant Bolshaya Udina Volcano
}

\author{
S. L. Senyukov ${ }^{a, b}, *$, V. O. Mikhailov ${ }^{b}$, I. N. Nuzhdina ${ }^{a}$, E. A. Kiseleva ${ }^{b, \dagger}$, \\ S. Ya. Droznina ${ }^{a}$, V. A. Timofeeva ${ }^{b}$, M. S. Volkova ${ }^{b}$, N. M. Shapiro ${ }^{b, c}$, \\ T. Yu. Kozhevnikova ${ }^{a}$, Z. A. Nazarova ${ }^{a}$, and O. V. Sobolevskaya ${ }^{a}$ \\ ${ }^{a}$ Kamchatka Branch of the Federal Research Center, Geophysical Survey, \\ Russian Academy of Sciences, bulvar Piipa, 9, Petropavlovsk-Kamchatsky, 683006 Russia \\ ${ }^{b}$ Schmidt Institute of Physics of the Earth, Russian Academy of Sciences, \\ Bolshaya Gruzinskaya, 10, str. 1, Moscow, 123242 Russia \\ ${ }^{c}$ Institute des Sciences de la Terre, Université Grenoble Alpes, CNRS (UMR5275), 1381, rue de la Piscine, Gieres, 38610 France \\ *e-mail: ssl@emsd.ru \\ Received April 10, 2020; revised April 23, 2020; accepted June 1, 2020
}

\begin{abstract}
Seismicity began to be recorded in October 2017 around the dormant Bolshaya Udina Volcano (B. Udina in what follows) situated $10 \mathrm{~km}$ southeast of Plosky Tolbachik Volcano. Seismic tomography showed the existence of a long-lived magma chamber south of B. Udina in the area of the Tolud River. The chamber has its top at a depth of about $15 \mathrm{~km}$, and may probably be connected to the Plosky Tolbachik plumbing system (Koulakov et al., 2017). Saltykov et al. (2018) and Koulakov et al. (2019) related the observed resumption of seismic activity to a hypothetical emplacement of magma beneath the Udina volcanoes, pointing out a high likelihood of the resumption of volcanic activity. The present study examines data from permanent seismic stations showing a systematic displacement of the center of seismic energy southward from B. Udina from October 2017 through August 2019. The center characterizes the location of the volume that generates the bulk of seismicity. We used images of the Sentinel-1A satellite (wavelength $5.6 \mathrm{~cm}$ ) taken from a descending orbit of track 60 during the period from June 7, 2017 through September 23, 2017 (10 images) and during the period from May 21, 2018 to September 30, 2018 (12 images) to determine time series and average velocities of displacement on the slopes of B. Udina. Persistent scatterers could only be identified at the foot of B. Udina. An analysis of displacement time series for the surface of the volcano showed that the character of displacements in 2017 and 2018 on the southwestern and eastern slopes remained nearly the same, while the average rate of displacement on the northwestern slope decreased in 2018. We used three images of the ALOS-2 PALSAR-2 satellite (wavelength $23.5 \mathrm{~cm}$ ) taken on October 4, 2016, June 13, 2016, and October 2, 2018 from an ascending orbit to construct paired interferograms, which characterize displacements for the time period between images. The displacements on both interferograms did not exceed a few centimeters, except for narrow zones confined to local relief forms. The deformations thus detected were most likely due to surface processes. The deformed volumes related to pressure changes in the magma chamber at a depth of $5 \mathrm{~km}$ must have linear dimensions of $10-15 \mathrm{~km}$, while the displacement areas detected in the satellite images are considerably smaller. These results suggested an alternative model that postulates the resumption of seismic activity to accompany the retreat and sinking of magma melt from B. Udina into the chamber in the Tolud R. area as identified by tomographic techniques.
\end{abstract}

Keywords: Bolshaya Udina Volcano, seismicity monitoring, SAR interferometry, seismicity migration, resumption of volcanic activity

DOI: $10.1134 / \mathrm{S} 074204632005005 \mathrm{X}$

\section{INTRODUCTION}

The Tolbachik Fissure Eruption named after the 50 years of the Institute of Volcanology and Seismology (TFE-50 in what follows) began on November 27, 2012 and lasted until September 2013 (Samoilenko

\footnotetext{
${ }^{\dagger}$ Deceased.
}

et al., 2012; Tolbachinskoe ..., 2017; Senyukov et al., 2015). Five years since its termination, starting October 2017, comparatively weak earthquakes began to occur near the dormant B. Udina Volcano which is situated $10 \mathrm{~km}$ southeast of Plosky Tolbachik Volcano (Pl. Tolbachik) (Fig. 1). This seismic activation excited great interest among volcanologists and seis- 
mologists in connection with a possible "awakening" of B. Udina. The composition of the rocks that make up the Udina volcanoes implies their primary magma to be generated in a shallow intermediate magma chamber (Maksimov, 1976; Timerbaeva, 1967). Kulakov et al. (2017) used data provided by a network consisting of permanent and temporary seismic stations to develop a seismotomographic model of the crust beneath the Klyuchevskoi Group volcanoes. According to this model, a long-lived magma chamber is situated in the area of the Tolud River south of B. Udina; the chamber top is at a depth of $\sim 15 \mathrm{~km}$, and the chamber may be connected to the Pl. Tolbachik plumbing system. A team of workers from the Kamchatka Branch of the Federal Research Center (FRC) at the Geophysical Survey of the Russian Academy of Sciences (GS RAS) studied the earthquakes occurring in the Udina volcanoes area using the SOUS"09 method (Saltykov, 2011). The results reported in (Saltykov et al., 2018) were summed up as follows: "A growth of seismicity was observed in October 2017 reaching a high level to be followed by an extremely high level in all the time windows considered in November. At present (late March 2018) the high seismicity in the Udina Volcano area continues, with the seismicity level being characterized as extremely high in all the time windows considered". As well, the reference quoted above pointed out a possible emplacement of magma beneath the Udina volcanoes and the likelihood of an eruption with a probability of $64 \%$. The seismicity continued to be studied using a temporary network of stations installed in the B. Udina area from May through July 2018 (Koulakov et al., 2019). The main results of the study of over 500 earthquakes that have been recorded during that period are as follows: (1) a linearly elongate, elliptic cluster of earthquakes has been recorded, which connects B. Udina and the Tolud R. area; (2) the seismic cluster beneath B. Udina may mark an active magma chamber situated below a depth of $5 \mathrm{~km}$; (3) magma began migrating in late 2017 from the chamber in the Tolud R. area situated in the middle and lower crust northward to B. Udina Volcano. This suggested the inference of a possible resumption of activity for $\mathrm{B}$. Udina.

In other words, the studies referred to above related, as is usually done, the resumption of seismic activity to magma emplacement providing evidence of a possible resumption of volcanic activity. We propose an alternative model based on an analysis of seismic and satellite data; this model explains the resumption of seismic activity mentioned above by the retreat and sinking of the magma melt from B. Udina Volcano into the chamber that was identified by seismic tomography to be situated in the Tolud $\mathrm{R}$. area.

\section{SEISMOLOGICAL OBSERVATIONS}

\section{The Data and the Method of Study}

The Kamchatka Branch (KB) of the FRC GS RAS (http://www.emsd.ru/) started a seismicity monitoring of volcanic areas in Kamchatka in near real time since $2000 \quad$ (http://www.emsd.ru/ ssl/monitoring/main.htm) (Senyukov, 2013). The Laboratory of Studies in Seismic and Volcanic Activity at the KB FRC GS RAS takes part in the monitoring by locating all earthquakes and inserting the results into the web survey data base (http://www.emsd.ru/ts/). The data base is used to make a free-access "Unified Information System of Seismological Data" (http://www.emsd.ru/sdis/main.php) (Chebrova et al., 2015). The catalogs of regional and volcanic earthquakes for 1999-2018 and associated research papers have been published in the FRC GS RAS Earthquakes of North Eurasia and Earthquakes in Russia collections of papers issued by the FRC GS RAS (see, e.g., Chebrov et al., 2019a; Senyukov et al., 2019).

Figure 1a presents a map of earthquake epicenters as recorded by the network of permanent seismic stations operated by the KB FRC GS RAS in the area of study (Chebrov et al., 2013, 2019b) for the period from January 1, 2000 through January 1, 2019. Figure 1b shows earthquake hypocenters projected onto the vertical cross-section1-2 (see Fig. 1a). Our analysis of seismic data used a subdivision of the area of study into six equal-area, $\sim 11-\mathrm{km}$, squares. The square boundaries were chosen so as to have the volcanoes in the middle of the squares and the boundaries would bisect the intervolcano distances (see Fig. 1). The ultimate result was to have square (A) with fewer earthquakes, while the five remaining squares included areas with large numbers of seismic events: the active Pl. Tolbachik volcano $(\mathrm{C})$, the dormant volcanoes Zimina (B) and B. Udina (D), Tolbachik Dol (E), and the Tolud R. area $(\mathrm{F})$. It should be noted that square $(\mathrm{C})$ contains the TFE-50 area (Tolbachinskoe ..., 2017; Senyukov et al., 2015), while square (E) encloses the area of the Great Tolbachik Fissure Eruption of 1975-1976 (GTFE) (The Great Tolbachik ..., 1984). For the six squares we made selections of earthquakes for depths equal to or less than $40 \mathrm{~km}$ using the POLYGON program and found daily Seismic Energy Centers (SEC) for each selection using the CenterEnergy program (authored by V.E. Bliznetsov). This program inspects all earthquakes for a 24-hour period to find a SEC, which is an equivalent earthquake with hypocenter coordinates that are arithmetic means of those of the earthquakes recorded during the 24-hour period of interest using weights directly proportional to the energy of the constituent events. The energy of the equivalent earthquake is equal to the sum of energies of the selected events, and the energy class $K_{\mathrm{S}}$ (Fedotov, 1972) is equal to the common logarithm of the total energy. 
(a)

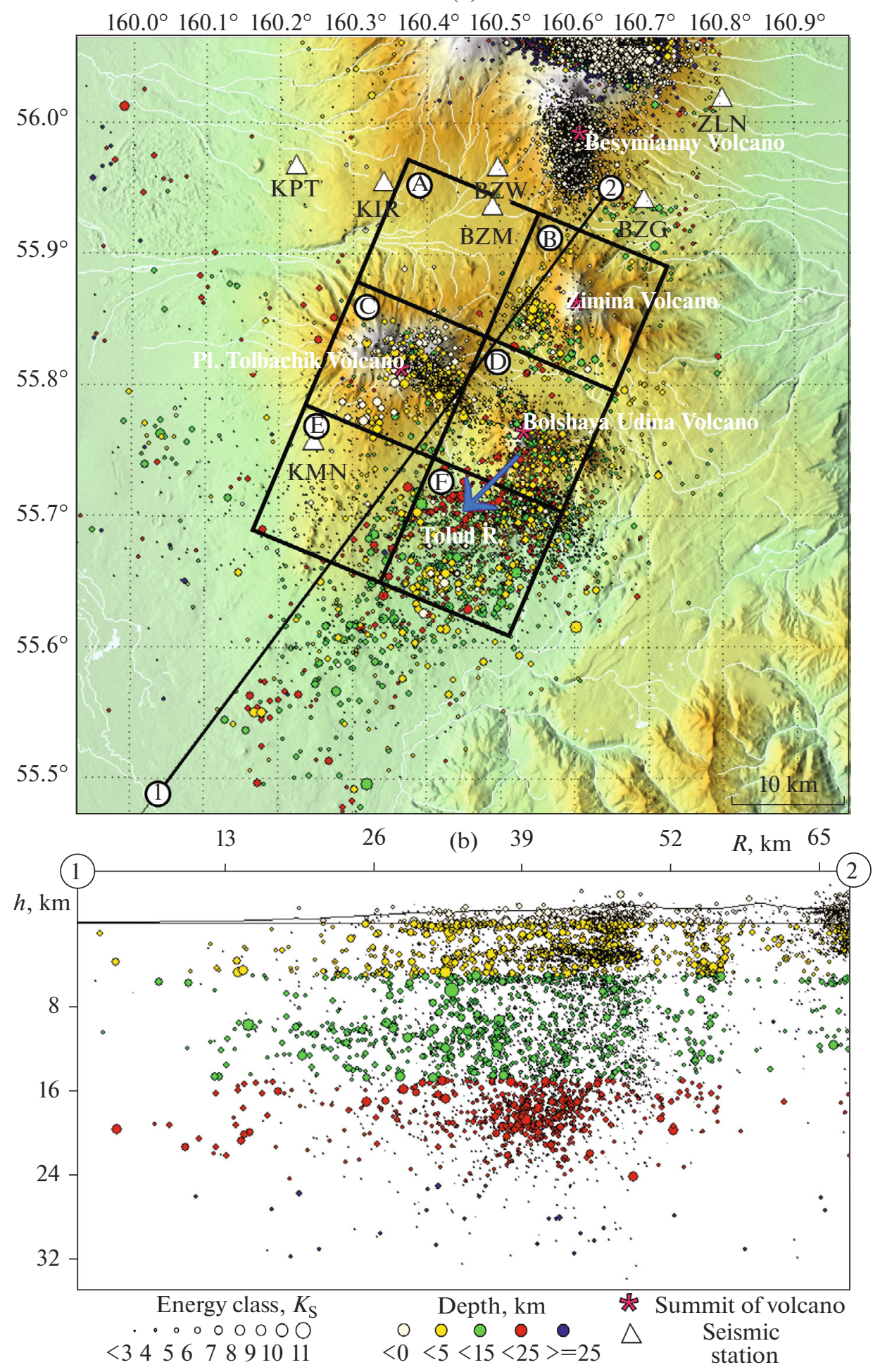

Fig. 1. A map of earthquake epicenters (a) and their hypocenters projected onto the vertical cross-section 1-2 (b) for the events occurring in the area of study from January 1, 2000 to August 21, 2019. The white triangles mark seismic stations operated by the KB FRC GS RAS. The stations that began operation prior to 2000 are ZLN, KPT, and KMN. For the other stations the starting date is indicated in parentheses: KIR (August, 2006), BZM (September 2006), BZG (September 2007), and BZW (September 2007). The blue arrow shows the migration of the seismic energy center from October 2017 through August 2019. 


\section{Results and Discussion}

Figure 2 shows plots of two SEC parameters, viz., depth and $K_{\mathrm{S}}$. We begin with the parameter $K_{\mathrm{S}}$ as an indicator of seismic activity in the squares. We wish to note the following features as being important for seismicity monitoring.

(1) Zone A (see Fig. 2a) shows the lowest seismicity of all with a total of 56 events whose $K_{\mathrm{S}}$ varies from 2.0 to 6.2. We recorded a slight rise of activity that was simultaneous with the beginning of the TFE-50.

(2) Zone B (the Zimina volcanoes, see Fig. 2b) contains 413 events with $K_{\mathrm{S}}$ between 2.1 and 8.5. There was a considerable burst of activity on September 5, 2006 (up to $K_{\mathrm{S}}=8.0$ ). Before and at the start of the TFE-50, the values of $K_{\mathrm{S}}$ reached 8.5, with the respective figure for the initial activation of $\mathrm{B}$. Udina being 7.7 (April 1, 2019).

(3) Zone C (Pl. Tolbachik Volcano and the TFE-50, see Fig. 2c) contains 1398 events with $K_{\mathrm{S}}$ between 2.0 and 9.4. There was a considerable increasing burst of activity ( $K_{\mathrm{S}}$ between 5.5 and 9.6 ) three months before the TFE-50, which lasted until August 21, 2019, beyond the end of the TFE-50, at a level above that of the 2000-2009 seismicity.

(4) Zone D (B. Udina Volcano, see Fig. 2d). A total of 1507 events were recorded with $K_{\mathrm{S}}$ between 2.0 and 7.7. There was a slight rise of activity simultaneously with the start of the TFE-50 and a considerable one from October 2017 through August 21, 2019. The maximum of the $K_{\mathrm{S}}$ fitted function in the last burst was observed in late March 2018 with subsequent decrease in seismicity. With regard to the last burst, one also notes a gradual persistent lowering of SEC depth from $\sim 5$ to $\sim 15 \mathrm{~km}$.

(5) Zone E (Tolbachik Dol and the GTFE, see Fig. 2e). A total of 329 events were located with $K_{\mathrm{S}}$ from 2.4 to 9.8. There was a slight short-lived burst of activity on November 30, 2012 at once after the start of the TFE-50 $\left(K_{\mathrm{S}}\right.$ reaching 7.0$)$ and some low activity at depths of 20-25 km since December 2018.

(6) Zone F (Tolud R., see Fig 2f) contains 1489 events with $K_{\mathrm{S}}$ between 2.7 and 11.3. There was a considerable short-lived burst of activity on November 30 , 2012 at once after the start of the TFE-50 $\left(K_{\mathrm{S}}\right.$ reached 11.3 ), an increased activity after the termination of the TFE-50, and a considerable long burst since March 2018. With regard to the last burst of activity, the maximum of the $K_{\mathrm{S}}$ fitted function occurred from December 2018 through February 2019; this was followed by some diminution of seismic activity. The values of SEC depth were in the range $\sim 10$ to $\sim 15 \mathrm{~km}$ during the period.

One remark seems to be in place at this point for a correct assessment of these results. The catalog provides the following average estimates of location uncertainty for earthquakes falling in the area of study: 0.5 for $K_{\mathrm{S}} ; \pm 3 \mathrm{~km}$ for the average location uncertainty in map view, with the maximum error reaching $\pm 7 \mathrm{~km}$.
The average location uncertainty for depth determination is $\pm 3 \mathrm{~km}$, with the maximum error being $\pm 11 \mathrm{~km}$. Consequently, it seems impossible to analyze the epicenter bias by examining individual events. At the same time, Koulakov et al. (2019, Fig. 3.1) showed that the scatter in epicenters for squares $\mathrm{D}$ and $\mathrm{F}$ based on a denser network of temporary stations is significantly smaller than that for the network of permanent stations. As well, many studies revealed the fact that on relocating, the epicenters concentrated around certain local sources, such as faults or compact areas. It would thus appear that the sources of seismicity are small in size, while the scatter of epicenters is largely due to a poor observing system, an inaccurate velocity model, as well as many other factors, including subjective ones.

The results presented in Fig. 2 are based on a study of two parameters, $K_{\mathrm{S}}$ and depth of the SEC, which are found by summing up the respective values for individual events in time windows. The value of $K_{\mathrm{S}}$ is found as the common logarithm of a sum of energies, hence it is largely controlled by the event of the highest energy in the current 24-hour period (since energy is 10 raised to the power of $K_{\mathrm{S}}$ ) and the uncertainty of the energy class estimate for that event. For this reason a change of over 0.5 in $K_{\mathrm{S}}$ can be judged significant. At the same time, the uncertainty in SEC location (latitude, longitude, and depth) depends on the number of quantities being summed, and is inversely proportional to the square root of the number of events involved in the summation. As an example, assuming the uncertainty of hypocenter depth determination to be $10 \mathrm{~km}$, and the summation involves 9 events, then the uncertainty of SEC depth would be $10 / \sqrt{9}=3.3 \mathrm{~km}$.

To verify the resulting estimates of SEC depth variation and its migration in map view we calculated the SEC parameters for all events in squares $\mathrm{D}$ and $\mathrm{F}$ (see Fig. 1a) between October 1, 2017 and August 21, 2019, applying summation over months rather than over days. The monthly plots (Fig. 3) clearly reveal linear trends in latitude variation of $\sim 4 \mathrm{~km}$ from north $\left(55.740^{\circ}\right)$ to south $\left(55.705^{\circ}\right)$, and in longitude, also by about $4 \mathrm{~km}$, from east $\left(160.555^{\circ}\right)$ to west $\left(160.474^{\circ}\right)$, the corresponding depth variation being from 5 to $15 \mathrm{~km}$. The lateral seismicity migration corresponding to these trends is shown by a blue arrow in Fig. 1a. As well, the plot of energy variation, $K_{\mathrm{S}}$ (see Fig. $3 \mathrm{~b}$ ), shows a diminution of total seismicity in squares $D$ (B. Udina) and F (Tolud R.) beginning February 2019. It follows from the histogram in Fig. $3 \mathrm{c}$ that the uncertainty of parameter determination based on monthly data must be at least 5 times less than the error of determination for a single event, which means that the number of events being summed varied from 25 to 150 .

We did some more research in order to lend support to these results. The original data series were diminished by successively eliminating earthquakes and the result was compared with that based on all events. At 


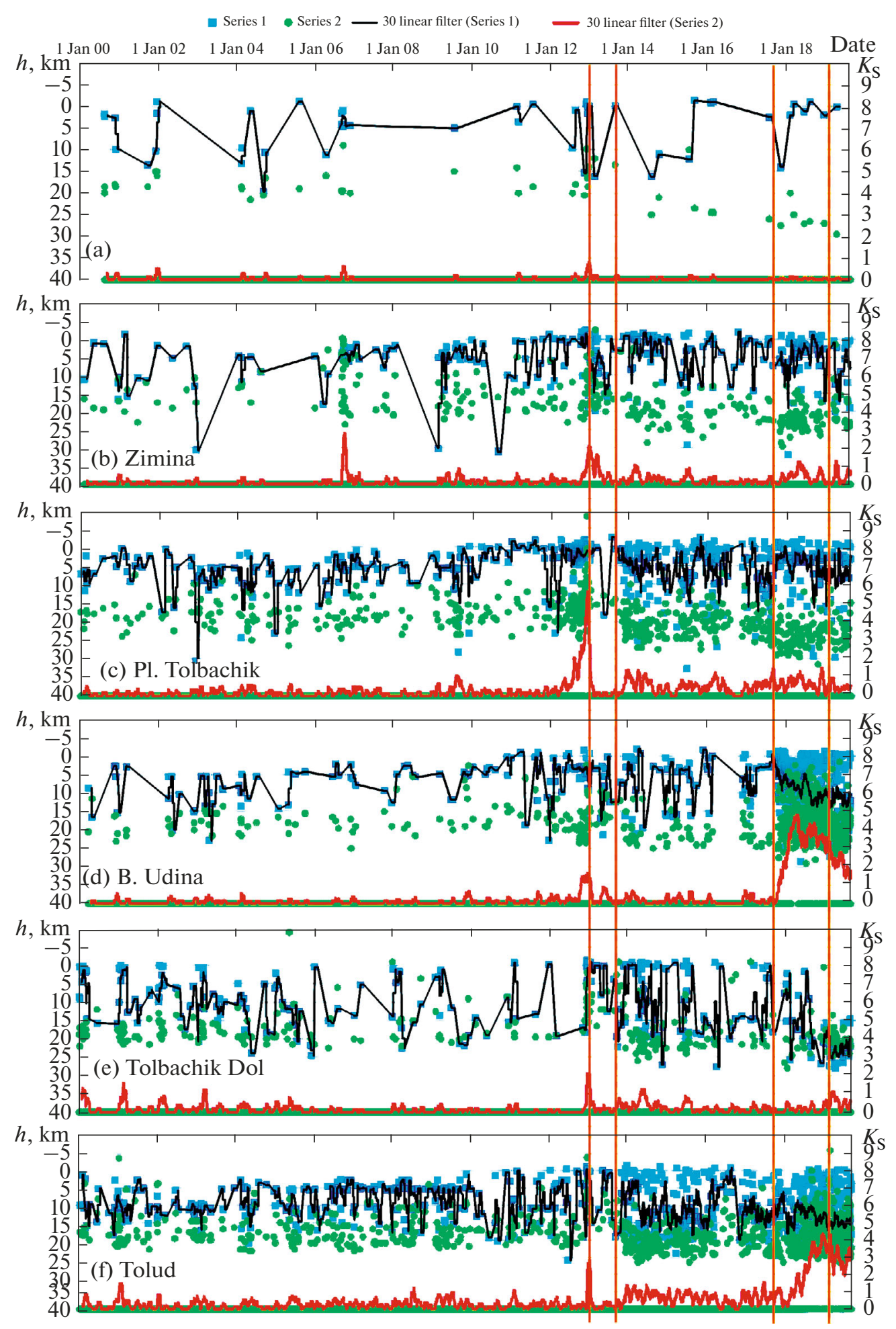

Fig. 2. Plots showing the time-dependent variation in depth and energy $\left(K_{\mathrm{S}}\right)$ for the daily SEC based on earthquakes occurring in squares A through f (see Fig. 1a). Time series 1 (in blue, left axis) is for SEC depth, time series 2 (in green, right axis) is for SEC $K_{\mathrm{S}}$. The black line represents average depth in a moving window of 30 values and the red line shows average SEC $K_{\mathrm{S}}$ based on 30 daily values. The two vertical orange lines on the left mark the start and end of the TFE-50, the third line marks the start of seismicity increase on October 1, 2017, and the fourth line is at February 2019. For the legend (a-f) see main text. 


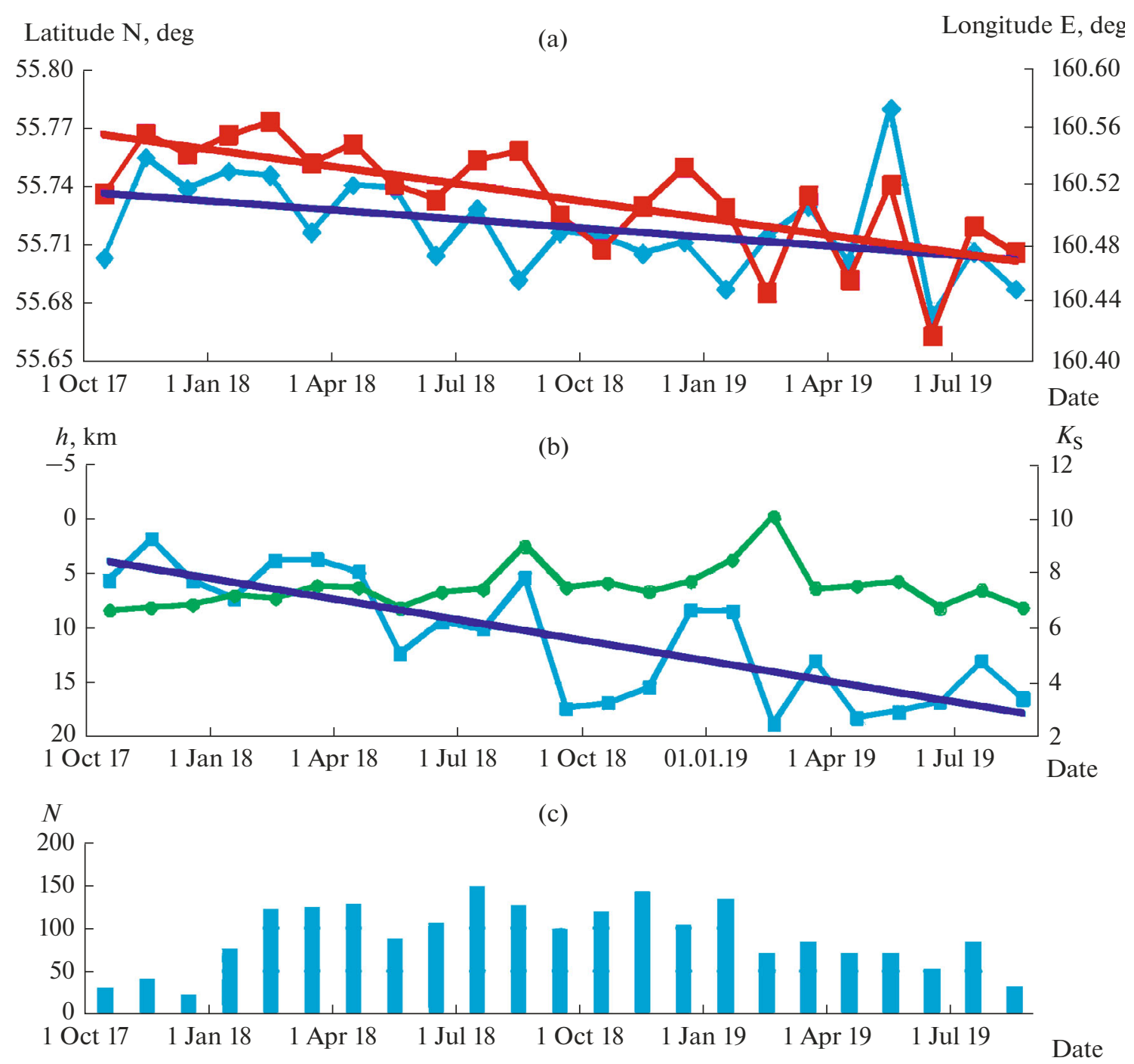

Fig. 3. Plots showing the time-dependent SEC variation in the latitude (in blue, left axis) and in longitude (in red, right axis) along with linear trends of the respective colors (a). The depth (in blue, left axis) and total energy converted to energy class $K_{\mathrm{S}}$ (in green, right axis) plotted against time (b). The SEC parameters were calculated for the earthquakes occurring in squares D (B. Udina) and F (Tolud R.), see Fig. 1a for the period of October 1, 2017 to August 21, 2019 in a time window of one month. A histogram showing the numbers of earthquakes involved in monthly determinations of the SEC parameters (c).

first we eliminated every 10th earthquake from the original observations, then every 5th, every 3 rd, and every 2 nd. This procedure showed that the elimination had little effect on the ultimate result, thus showing that the result itself was reliable (Fig. 4).

To sum up, our analysis of seismic data indicated a retreat and sinking of the SEC away from B. Udina Volcano.

\section{ESTIMATING GROUND DISPLACEMENTS BASED ON SATELLITE OBSERVATIONS}

\section{The Data Set and Methods of Study}

The migration of magma material must be accompanied by ground deformation. Since the topography of the surface of volcanoes can change due to many factors, it is useful to assess the size of the displacement area in relation to the depth to the magma chamber. To do this, we may make use, to a first approximation, of the solution to a problem on stress and strain due to the expansion or contraction of a small spherical volume in an elastic half-space bounded by a free surface (Mogi, 1958). The rise of magma material from depth must produce a corresponding pressure increase in the magma chamber, hence some deformation of the surrounding half-space and the free surface. The retreat of magma material to greater depth must produce substantially lower ground displacements, because it is not accompanied by any considerable pressure change in the magma chamber. We note that there are publications providing solutions for more complex geometries and more complex rheologies (see Bonafede and Ferrari, 2009 and the refer- 


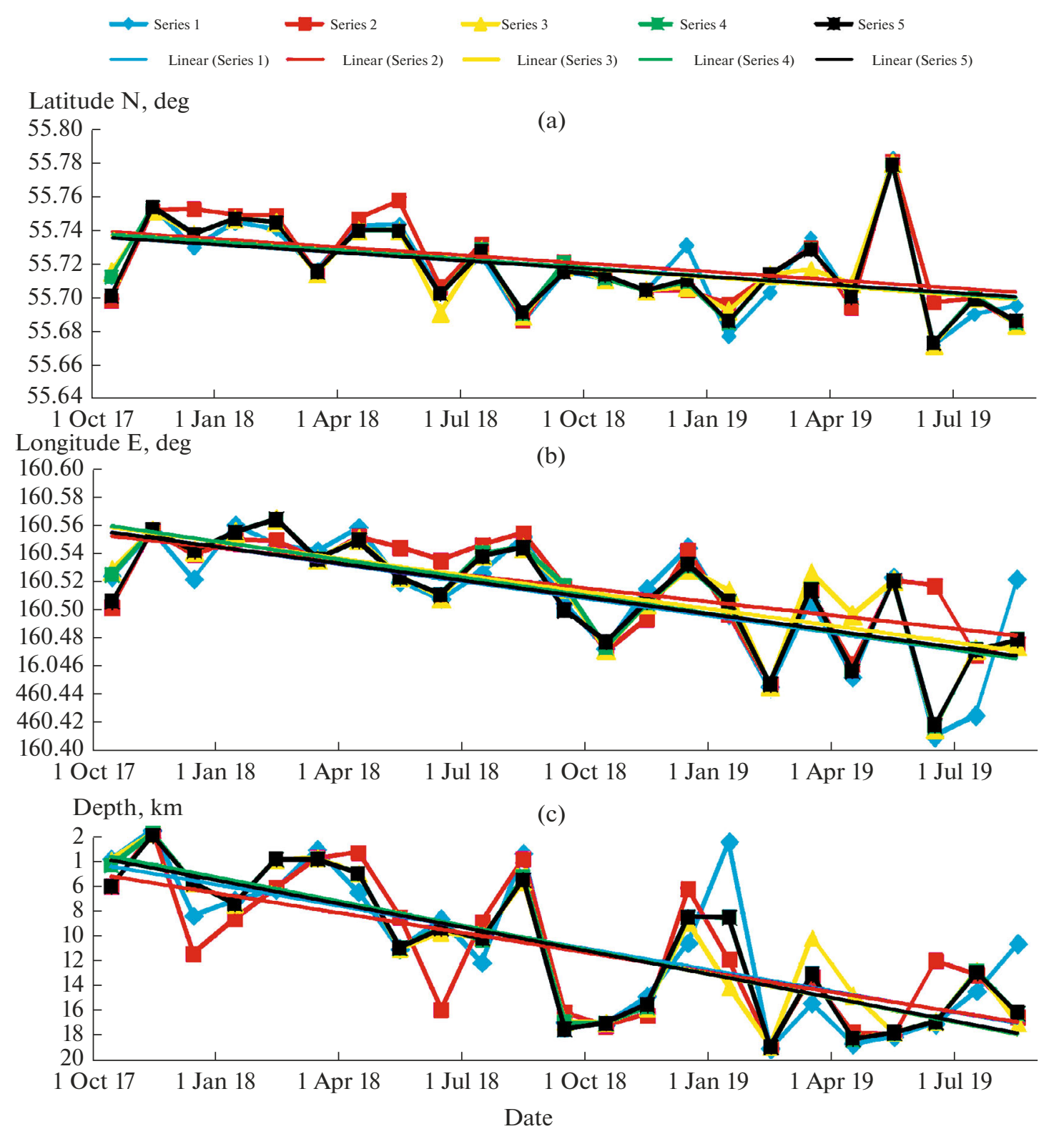

Fig. 4. The latitude (a), longitude (b), and depth (c) of the SEC plotted against time and the corresponding linear trends based on 1-month averaging with every other earthquake eliminated from consideration (time series 1 , blue), every third (time series 2 , red), every 5 th (time series 3 , yellow), and every 10th earthquake (time series 4 , green). Time series 5 (black) is based on the full sample.

ences therein), but as the depth to the magma chamber increases, all solutions reduce to the strain a point source. We make use of the Mogi solution to assess the size of the displacement region on the ground surface in relation to the depth to a magma chamber. If Poisson's ratio is known, the ground displacements depend on chamber depth alone (formulas (2) in Bonafede and Ferrari, 2009). Denote chamber depth by d and let Poisson's ratio be 0.25 . In that case the distance between the point where the ground displacement reaches its maximum (this point is above the chamber center) and the point where the displacement is half the maximum is $0.77 \mathrm{~d}$. The distance to the point where the displacement is 0.2 of the maximum value is $1.39 \mathrm{~d}$. It follows that, if ground displacements are due to a pressure change in a magma chamber at a depth of $5 \mathrm{~km}$, then the displaced area would be $7.7 \mathrm{~km}$ wide when measured along the 0.5 -maximum isoline, with the corresponding width when based on the 0.2maximum isoline being about $14 \mathrm{~km}$.

We analyzed surface displacement on the volcano for 2017 and 2018 using images from the Sentinel-1A satellite (wavelength $5.6 \mathrm{~cm}$ ) taken from a descending orbit, track 60 . We found 10 images in the archives of 
the European Space Agency for the period between June 7, 2017 and September 23, 2017 and 12 images for the period from May 21, 2018 through September 30, 2018.

The Sentinel-1A and B satellites, as well as other satellites equipped with synthetic-aperture radar (SAR) instruments, provide a means for active remote sounding of the Earth. The satellite radar emits pulses to the Earth's surface at an angle to the vertical and receives the reflected signal. Two radar images can be used to estimate the phase shift between signals at the first and the second image, provided we know the height of the scatterer above the ellipsoid (digital elevation model, DEM). The phase shift when appropriately corrected can be used to estimate the displacement of the scatterer along the line of propagation of the radar signal, i.e., along the line toward the satellite, the so-called line of sight or LOS (Dmitriev et al., 2012; Mikhailov et al., 2013).

The quality of the interferogram based on two images depends on atmospheric delay, the uncertainty in orbit specification and DEM, and noise level. In order to enhance the accuracy of displacement determination, methods were proposed based on a joint analysis of interferogram series and identification of objects that are clearly seen in all images, the so-called methods of persistent scatterers (PS). Since in this search for PSs, the analysis is not only in space, but also over time, one can effectively filter various types of noise and identify displacements at rates of a few millimeters per year (a review and references can be found in Kiseleva et al., 2017).

This study uses the small-baseline method (SBAS), which is effective for the analysis of displacements of PSs in natural terrains. The first step was to construct interferograms based on pairs of images using the SRTM3v4 DEM. After this, we set up a search for persistent scatterers on the volcano's slopes. This analysis was carried out separately for 2017 and 2018 (Fig. 5) using the SARScape program package.

The area of study was also radar surveyed by the ALOS-2 PALSAR-2 satellite operated by the Japanese Space Agency (wavelength $23.5 \mathrm{~cm}$ ). Longer electromagnetic waves are less sensitive to atmospheric effects, they penetrate through vegetation and moderately deep snow, so that these images are preferable for estimating displacements in natural terrains. At the same time, the longer the wavelength, the lower is terrain resolution (because pixel size is larger) and the lower is the accuracy of displacement estimates. This can be easily seen as follows. Corresponding to one and the same phase shift on an interferogram based on ALOS-2 images is a 4-fold larger displacement compared with that based on Sentinel-1 images. In addition, ALOS-2 has a longer interval between observations for Kamchatka. A total of 5 images were taken for the period 2016-2018 for the study area; of these, three could be used to construct paired interfero- grams, yielding the pairs of October 4, 2016 to June 13, 2017 and June 13, 2017 to October 2, 2018. Comparison of results based on images taken by different satellites with different wavelengths and using different methods is of importance for verification of the results.

\section{Results and Discussion}

Inspection of the Sentinel-1A images for 2017 and 2018 revealed PSs mostly at the foot of B. Udina (see Fig. 5). An analysis of displacement time series showed that the displacements on the southwestern and eastern slopes were nearly identical, with both the locations of areas of maximum displacement and the time series for regions A and B being the same in Fig. 6 . One notes a slight increase in average displacement rates in 2018, but the sense of movement remained the same, and the total displacements did not exceed 15$20 \mathrm{~mm}$ for the survey period. On the northwestern slope the average displacement rates changed, with slight displacements toward the satellite being observed in 2017 and near zero rates being recorded in 2018 (for the time series for region C see Fig. 6).

These results show that no significant displacements have been observed on the B. Udina slopes during imaging periods in 2017 and 2018. This usually indicates either a low activity of the volcano-tectonic processes or, which is more likely in the present case, the great depth of the processes that were responsible for higher seismic activity.

Since the images of the intermediate wavelength detected scatterers mostly at the foot of the volcanoes, we analyzed the displacements based on three ALOS-2 PALSAR-2 images. We constructed two paired interferograms for October 4, 2016 to June 13, 2017 and for June 13, 2017 to October 2, 2018, which characterize the displacements for the period between the images (Figs. 7a, 7b). The displacements for the period from October 2016 through June 2017 did not exceed a few centimeters, except for regions of low coherence. Coherence measures the correlation between the phase values of two SAR images, varying from 0 (no correlation) to 1 (the perfect correlation). The red lines in Figs. 7a and $7 \mathrm{~b}$ outline the areas where the coherence is below 0.35. Displacements could not be reliably estimated there.

The 2016-2018 displacements were not large, except for narrow zones where the displacements are obviously confined to local relief forms. As an example, the LOS displacements in the narrow zones lying in the upper part of the western B. Udina slope were 5-8 $\mathrm{cm}$ away from the satellite from October 2016 to June 2017, while for the period June 2017 through October 2018, the LOS displacements of $10-\mathrm{cm}$ amplitudes occurred in the opposite sense, toward the satellite. The detected deformations were most likely due to surface processes and to the variation in snow 

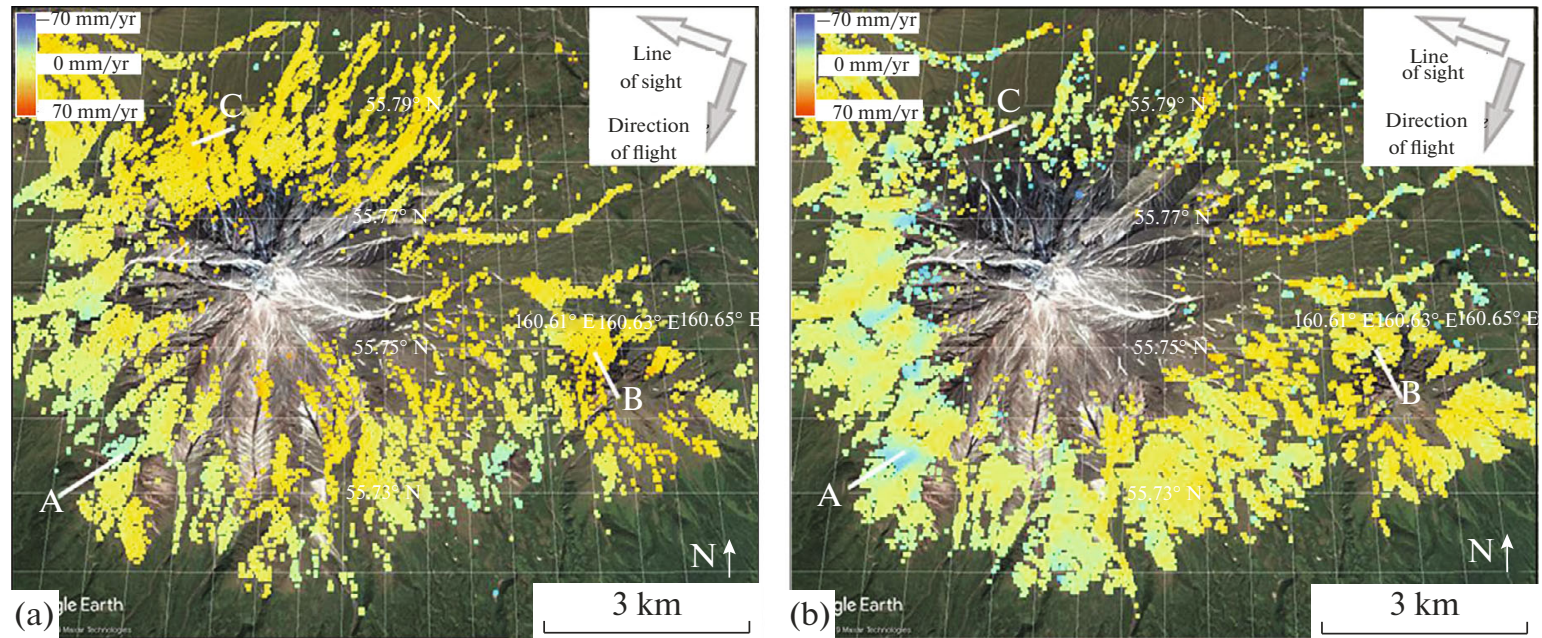

Fig. 5. The positions of persistent scatterers on the B. Udina slopes: survey period from June 7, 2017 to September 23, 2017 (a); survey period from May 21, 2018 to September 30, 2018 (b). The topographic background was based on an image at Google Earth. The color scale in the upper left corner represents average displacement rates between +70 and $-70 \mathrm{~mm} / \mathrm{yr}$. The blue persistent scatterers were displaced away from the satellite. The flight direction and the line of sight are shown by arrows in the upper right corner. The displacement time series for regions A through $\mathrm{C}$ are shown in Fig. 6.

(a)

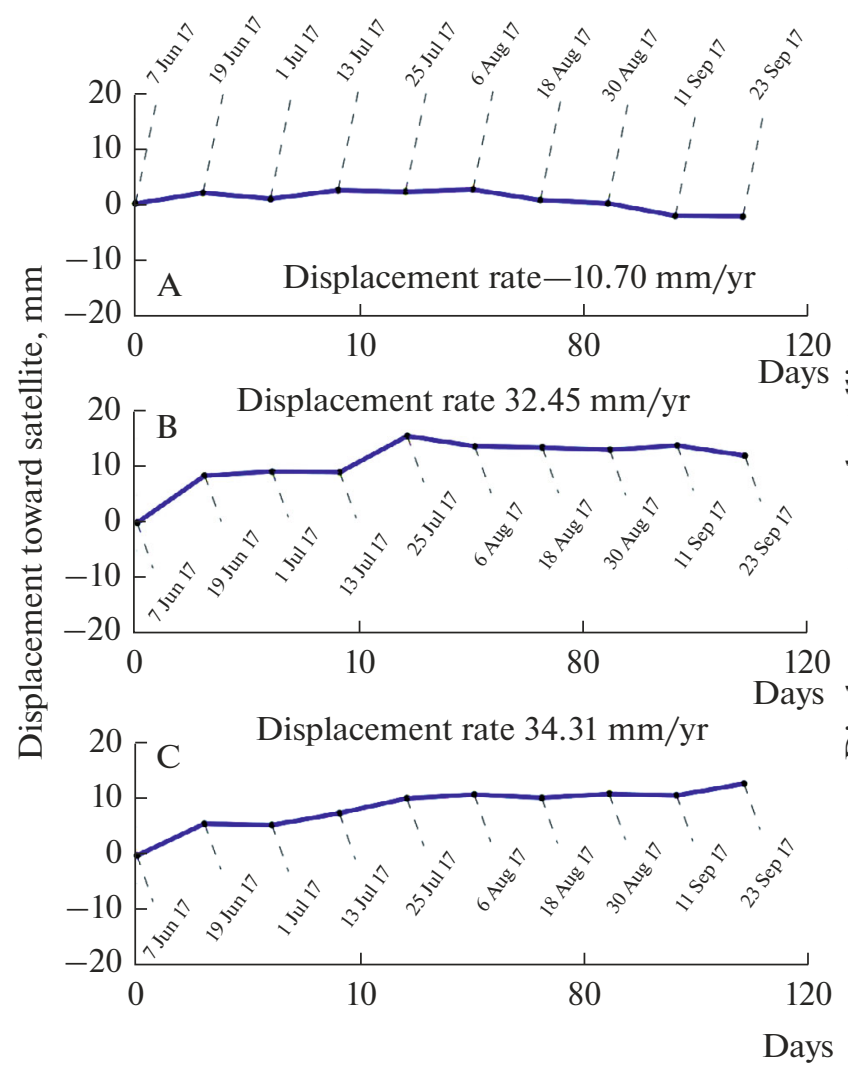

(b)

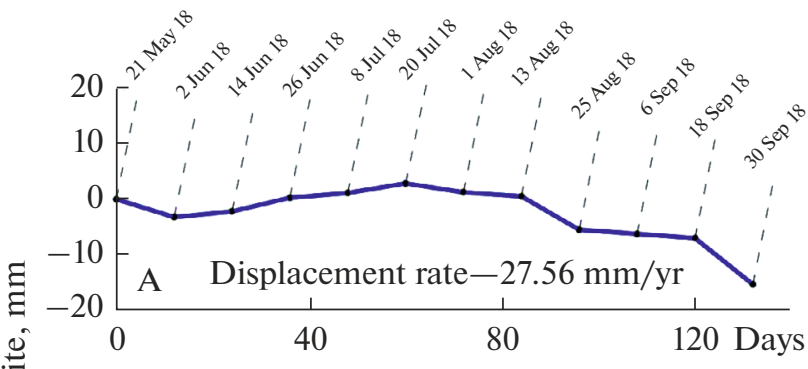

Fig. 6. The displacement time series for persistent scatterers on the B. Udina slopes: the survey period from June 7, 2017 to September 23, 2017 (a); the survey period from May 21, 2018 to September 30, 2018 (b). The areas marked A, B, C are specified in Fig. 5. The horizontal scale represents the survey time and the vertical scale shows displacement toward satellite in $\mathrm{mm}$. 
(a)

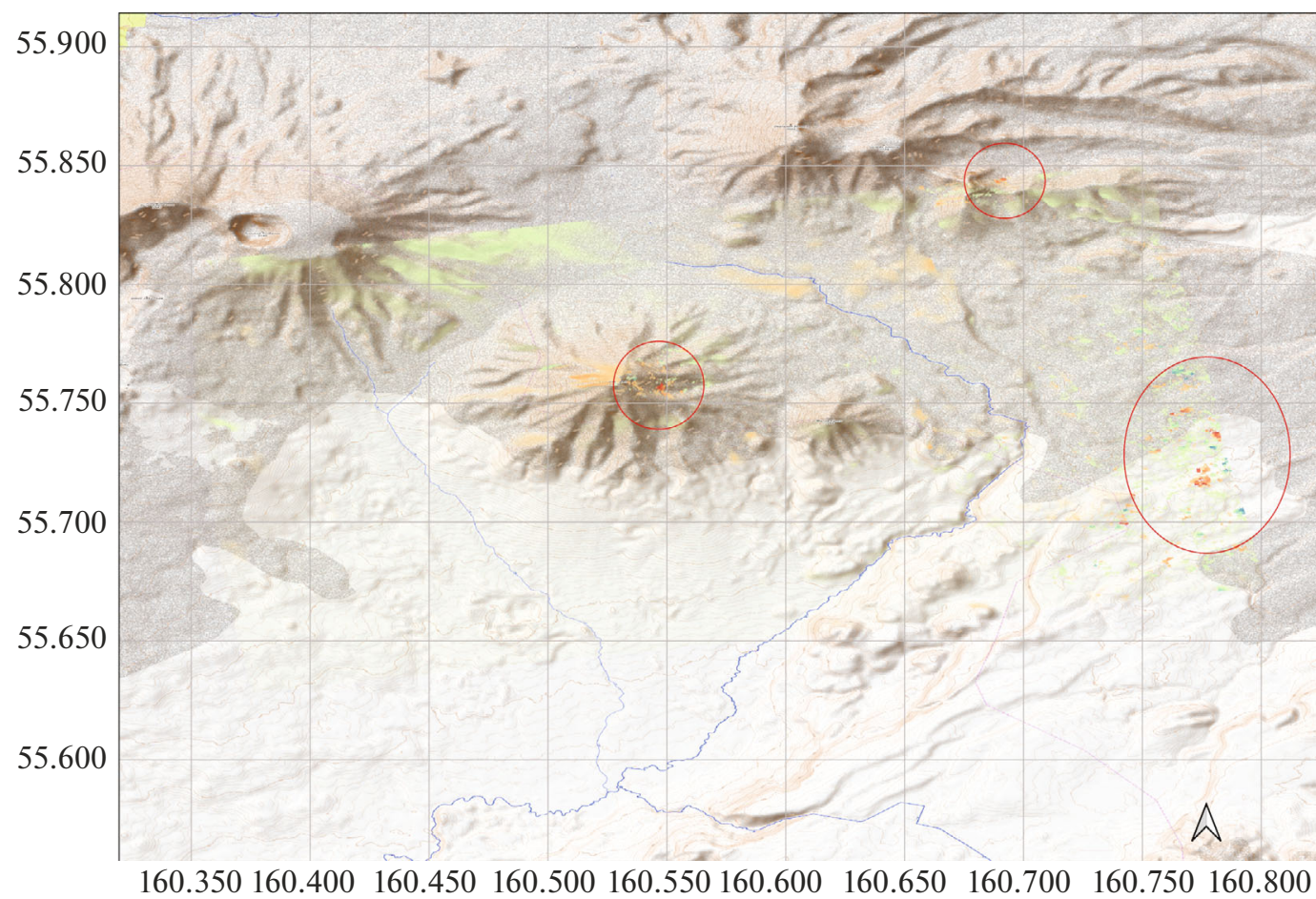

(b)

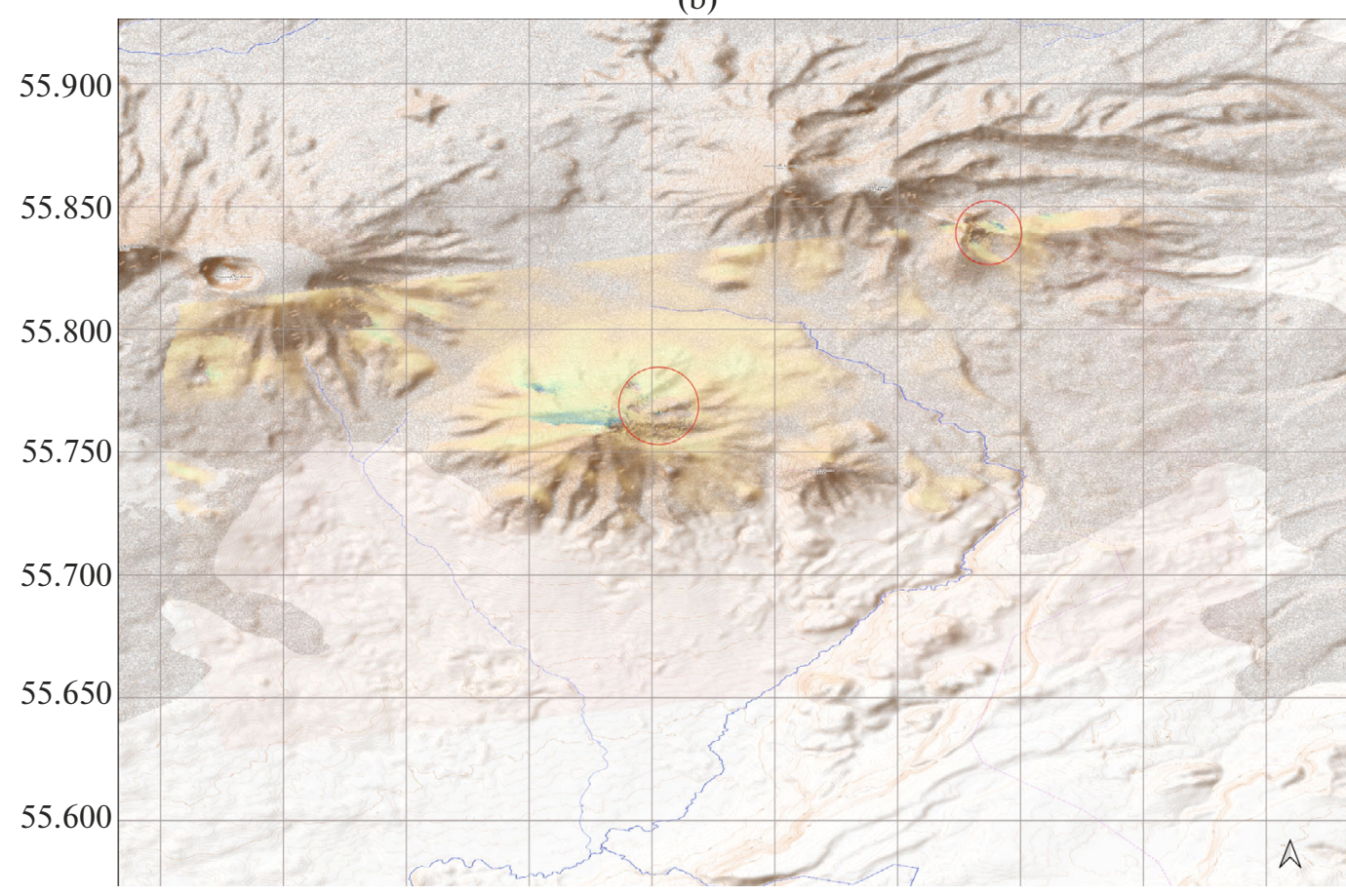

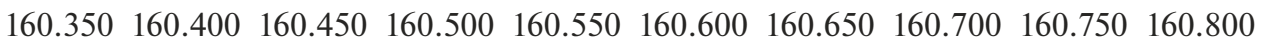

Displacement scale, $\mathrm{m}$

$-0.15$

$-0.12$

$-0.09$

$-0.06$

$-0.04$

0

0.02

0.05

0.08

0.11

0.14

0.17
Displacement scale, $\mathrm{m}$

$-0.12$

$-0.10$

$-0.08$

$-0.06$

$-0.04$

$-0.02$

0

0.02

Fig. 7. Displacements in map view (meters) derived from paired interferograms based on ALOS-2 PALSAR-2 images for the periods from October 4, 2016 to June 13, 2017 (a) and from June 13, 2017 to October 2, 2018 (b). The red contours enclose areas with low $(<0.35)$ coherence where displacement could not be determined with reliability. Negative values denote displacements from satellite, positive ones toward satellite. 
cover. According to the above estimates, the displaced regions due to activity of the magma chamber at a depth of $5 \mathrm{~km}$ must have linear dimensions of 10$15 \mathrm{~km}$ at the ground surface, corresponding to $0.1-$ 0.15 degrees latitude (2-3 squares of the geographic grid in Figs. 7a, 7b). No such displaced areas have been detected in the interferograms.

\section{CONCLUSIONS}

The above results based on a space-time analysis of earthquakes as reported in the KB FRC GS RAS catalog which contains data of permanent seismological observations are in good agreement with the results of independent studies based on data from temporary stations and with the results of SAR observations of ground surface deformation using images of the Sentinel-1A and ALOS- 2 satellites. We recall that the depth to the top of the magma chamber beneath B. Udina was estimated by Koulakov et al. (2019) as $\sim 5 \mathrm{~km}$, while that in the Tolud R. area is $\sim 15 \mathrm{~km}$ (Koulakov et al., 2017). Koulakov et al. (2019) also noticed a linearly elongate elliptical cluster of earthquakes that connects the chambers beneath $\mathrm{B}$. Udina and in the Tolud R. area. Our study of the SEC parameters (see Figs. 3,4 ) provided a clear demonstration of seismicity migrating from the $\mathrm{B}$. Udina chamber to the chamber in the Tolud R. area. The location of the blue arrow in Fig. 1 indicating the time-dependent SEC movement coincides with the earthquake cluster that connects the respective chambers beneath B. Udina and in the Tolud area. As well, we see coincidence as to depth: the SEC gradually subsides from depth $\sim 5 \mathrm{~km}$ beneath B. Udina to $\sim 15 \mathrm{~km}$ in the Tolud area. It thus appears that the observed seismic activity did not reflect resumption of B. Udina activity but rather the retreat and sinking of magma from this volcano into the chamber in the Tolud R. area that was identified by seismic tomography.

This result is also corroborated by satellite observations. No substantial ground deformation was observed in the B. Udina area as inferred from SAR images of the Sentinel-1A for 2017 and 2018 and of the ALOS-2 satellite for 2016-2018. The displacements as inferred may indicate either low activity of volcanotectonic processes or processes occurring at great depths. Hence we can conclude that, beginning mid2016, no evidence for emplacement of magma material from the Tolud chamber lying in the middle and lower crust northward toward B. Udina was detected. The important fact to remember is that ground deformation did occur based on SAR data before eruptions of Kizimen, Kamchatka (Lingyun et al., 2013), Pl. Tolbachik (TFE-50) (Lundgren et al., 2015), and Bezymianny (Mania et al., 2019).
The presence of a hydraulic connection between the Tolud R. area and the area of fissure eruptions on Plosky Tolbachik is also corroborated by the fact both in 1975 and in 2012, a few days after massive lava flows began to be discharged, large (class $\approx 11$ ) earthquakes were occurring in the Tolud R. area. The hydraulic connection described above makes B. Udina an unlikely location for the next eruption, because in that case magma would have to find a way upward through cooled, consolidated, and higher-lying (relative to Tolbachik Dol) rocks in the edifice of this dormant volcano. The results derived in the present study in combination with the previously observed facts suggest the inference that the dormant B. Udina volcano is an unlikely site for a new eruption.

The chief advantage of monitoring based on permanent stations is that we are able to follow the variation of seismicity during a long time span, in contrast to observations by temporary networks. For this reason the installation of even a single permanent station during the active period of Koryaksky Volcano in 2009 (Senyukov and Nuzhdina, 2011) and of Kizimen in 2010 (Senyukov et al., 2010) has enabled us, not only to make a correct assessment of the associated hazard (including a study of the SEC), but also to make a successful forecast of an eruption (Senyukov, 2013). Unfortunately, since the research funding for the Kamchatka Branch of the FRC GS RAS was reduced beginning 2013, no new permanent stations have been installed, so that the 2013-2015 eruption of Zhupanovsky Volcano and the 2017 eruption of Kambalnyi could be monitored using teleseismic stations alone, which extremely hampered accurate monitoring and hazard assessment.

\section{ACKNOWLEDGMENTS}

We are thankful to the Japan Aerospace Exploration Agency (JAXA) for providing the ALOS-2 PALSAR-2 SAR images under the ER2A2N075 research project, as well as the European Space Agency for images taken by the Sentinel-1A satellite.

\section{FUNDING}

This work was supported by the Ministry of Education and Science, project no. 14.W03.31.0033 (Geophysical Studies, Monitoring and Forecasting the Development of Catastrophic Geodynamic Processes in the Far East of the Russian Federation). The work of researchers affiliated with the KB FRC GS RAS was also supported for the project Multidisciplinary Geophysical Surveying of Volcanoes in Kamchatka and on the North Kuril Islands with a View to Detecting Signs of an Impending Eruption, as well as for Predicting Eruption Dynamics Involving Estimation of Ash Hazard for Aviation no. AAAA-A19-119031590060-3. The work of V.A. Timo- 
feeva was supported by the Russian Foundation for Basic Research, project no. 19-35-90092.

\section{REFERENCES}

Bonafede, M. and Ferrari, C., Analytical models of deformation and residual gravity changes due to a Mogi source in a viscoelastic medium, Tectonophysics, 2009, vol. 471, pp. 4-13.

Chebrov, V.N., Droznin, D.V., Kugaenko, Yu.A., Levina, V.I., Senyukov, S.L., Sergeev, V.A., Shevchenko, Yu.V., and Yashchuk, V.V., The system of detailed seismological observations in Kamchatka in 2011, J. Volcanol. Seismol., 2013, vol. 7, no. 1, pp. 16-36.

Chebrov, D.V., Chebrova, A.Yu., Matveenko, E.A., Droznina, S.Ya., Mityushkina, S.V., Gusev, A.A., Saltykov, V.A., and Voropaev, P.V., Kamchatka and the Commander Islands, in Zemletryaseniya Severnoi Evrazii, 2013 god (Earthquakes in North Eurasia, 2013), Obninsk: FITs EGS RAN, 2019a, pp. 198-213.

Chebrov, D.V., Droznina, S.Ya., Senyukov, S.L., Shevchenko, Yu.V., and Mityushkina, S.V., Kamchatk and the Commander Islands, in Zemletryaseniya Rossii v 2017 godu (Earthquakes in Russia in 2017), Obninsk: FITs EGS RAN, 2019b, pp. 67-76.

Chebrova, A.Yu., Chebrov, V.N., Matveenko, E.A., Tokarev, A.V., and Chemarev, A.S., The unified information system of seismological data at the Kamchatka Branch of the Geophysical Survey, Russian Academy of Sciences as of mid-2015. Contemporary methods for processing and interpretation of seismological data, in Materialy Desyatoi Mezhdunarodnoi seismologicheskoi shkoly Azerbaidzhana (Proc. 10th International Seismological School, Azerbaidzhan), Obninsk, September 14-18, 2015, Obninsk, 2015, pp. 356-360.

Dmitriev, P.N., Golubev, V.I., Isaev, Yu.S., Kiseleva, E.A., Mikhailov, V.O., and Smolyaninova, E.I., Some problems in the processing and interpretation of satellite radar interferometry data: The monitoring of land sliding processes, Sovremennye Problemy Distantsionnogo Zondirovaniya Zemli iz Kosmosa, 2012, vol. 9, no. 2, pp. 130-142.

Fedotov, S.A. Energeticheskaya klassifikatsiya Kurilo-Kamchatskikh zemletryasenii i problema magnitud (The Energy Classification of Earthquakes and the Magnitude Problem), Moscow: Nauka, 1972.

Koulakov, I., Abkadyrov, I., Al Arifi, N., Deev, E., Droznina, S., Gordeev, E.I., Jakovlev, A., El Khrepy, S., Kulakov, R.I., Kugaenko, Y., Novgorodova, A., Senyukov, S., Shapiro, N., Stupina, T., and West, M., Three different types of plumbing system beneath the neighboring active volcanoes of Tolbachik, Bezymianny, and Klyuchevskoy in Kamchatka, J. Geophys. Res., Solid Earth, 2017, vol. 122 , pp. 3852-3874.

https://doi.org/10.1002/2017JB014082

Kiseleva, E.A., Mikhailov, V.O., Smolyaninova, E.I., and Dmitriev, P.N., On monitoring ground movements by radar satellite-based interferometry, Sovremennye Problemy Distantsionnogo Zondirovaniya Zemli iz Kosmosa, 2017, vol. 14, no. 5, pp. 122-132.

Koulakov, I., Komzeleva, V., Abkadyrov, I., Kugaenko, Y., El Khrepy, S., and Al Arifi, N., Unrest of the Udina volcano in Kamchatka inferred from the analysis of seismicity and seismic tomography, Journal of Volcanology and Geothermal Research, 2019, vol. 379, pp. 4559.

https://doi.org/10.1016/j.jvolgeores.2019.05.006

Lingyun, Ji, Zhong, Lu, Dzurisin, D., and Senyukov, S., Pre-eruption deformation caused by dike intrusion beneath Kizimen volcano, Kamchatka, Russia, observed by InSAR, Journal of Volcanology and Geothermal Research, 2013, vol. 256, pp. 87-95.

https://doi.org/10.1016/j.jvolgeores.2013.02.011

Lundgren, P., Kiryukhin, A., Milillo, P., and Samsonov, S., Dike model for the 2012-2013 Tolbachik eruption constrained by satellite radar interferometry observations, Journal of Volcanology and Geothermal Research, 2015, vol. 307, pp. 79-88. https://doi.org/10.1016/j.jvolgeores.2015.05.011

Maksimov, A.P., Some geochemical features in the volcanoes of the Udina group, in Glubinnoe stroenie, seismichnost i sovremennaya deyatelnost Klyuchevskoi gruppy vulkanov (The Deep Structure, Seismicity, and Present-Day Activity of the Klyuchevskoi Group of Volcanoes), Ivanov, B.V. and Balesta, S.T., Editors-inChief, Vladivostok: DVNTs AN SSSR, 1976, pp. 7784.

Mania, R., Walter, T.R., Belousova, M., Belousov, A., and Senyukov, S.L., Deformations and morphology changes associated with the 2016-2017 eruption sequence at Bezymianny Volcano, Kamchatka, Remote Sens., 2019, vol. 11 , pp. 1278 .

https://doi.org/10.3390/rs11111278

Mikhailov, V.O., Kiseleva, E.A., Smolyaninova, E.I., Dmitriev, P.N., Golubeva, Yu.A., Isaev, Yu.S., Dorokhin, K.A., Timoshkina, E.P., Khairetdinov, S.A., and Golubev, V.I., Monitoring of landslide processes along a segment of the North Caucasian railway using satellite-based radar interferometry in various ranges of wavelength and corner scatterer, Geofiz. Issled., 2013, vol. 14. vol. 4, no. 5-22.

Mogi, K., Relation between the eruptions of various volcanoes and deformations of the ground surfaces around them, Bull. Earth. Res. Inst., 1958, vol. 36, pp. 99-134.

Saltykov, V.A., A statistical estimate of seismicity level: The method and results of application to Kamchatka, J. Volcanol. Seismol., 2011, vol. 5, no. 2, pp. 123-128.

Saltykov, V.A., Voropaev, P.V., Kugaenko, Yu.A., and Chebrov, D.V., The Udina seismicity increase in 20172018, Vestnik KRAUNTs, Nauki o Zemle, 2018, no. 1, issue 37 , pp. 5-7.

Samoilenko, S.B., Mel'nikov, D.V., Magus'kin, M.A., and Ovsyannikov, A.A., The beginning of a new Tolbachik fissure eruption in 2012, Vestnik KRAUNTs, Nauki o Zemle, 2012, no. 2, issue 20, pp. 20-22.

Senyukov, S.L., Monitoring and prediction of volcanic activity in Kamchatka from seismological data: 20002010, J. Volcanol. Seismol., 2013, vol. 7, no. 1, pp. 8697.

Senyukov, S.L. and Nuzhdina, I.N., The 1966-2009 seismicity of Koryakskii Volcano, in Trudy Vtoroi regional'noi nauchno-tekhnicheskoi konferentsii: Problemy kompleksnogo geofizicheskogo monitoringa Dal'nego Vostoka Rossii (Proc. Second regional conf. "Problems in Multidisciplinary Geophysical Monitoring of the Rus- 
sian Far East”), October 9-15, 2011, PetropavlovskKamchatskii: KF GS RAN, 2011, pp. 140-144.

Senyukov, S.L., Nuzhdina, I.N., Droznina, S.Ya., Garbuzova, V.T., Kozhevnikova, T.Yu., and Sobolevskaya. O.V., The seismicity of Kizimen Volcano, in Problemy kompleksnogo geofizicheskogo monitoringa Dalnego Vostoka Rossii (Problems of Multidisciplinary Monitoring of the Far East of Russia), Proc. Second conf., Petropavlovsk-Kamchatsky, October 11-17, 2009, Petropavlovsk-Kamchatsky: GS RAN, 2010, pp. 91-95.

Senyukov, S.L., Nuzhdina, I.N., Droznina, S.Y., et al., Seismic monitoring of the Plosky Tolbachik eruption in 2012-2013 (Kamchatka peninsula Russia), Journal of Volcanology and Geothermal Research, 2015, vol. 302, pp. $117-129$.

https://doi.org/10.1016/j.jvolgeores.2015.06.018
Senyukov, S.L., Nuzhdina, I.N., and Chebrov, D.V., The volcanoes of Kamchatka, in Zemletryseniya Rossii $v$ 2017 godu (Earthquakes in Russia in the Year 2017), Obninsk, 2019, pp. 93-103.

The Great Tolbachik Fissure Eruption: Geological and Geophysical Data, 1975-1976, Fedotov, S.A. and Marchinin, E.K., Eds., Cambridge University Press, 1983.

Timerbaeva, K.M., Petrologiya Klyuchevskikh vulkanov na Kamchatke (The Petrology of the Klyuchevskoi Volcanoes, Kamchatka), Moscow: Nauka, 1967.

Tolbachinskoe treshchinnoe izverzhenie 2012-2013 (The Tolbachik Fissure Eruption of 2012-2013), Gordeev, E.I. and Dobretsov, N.L., Editors-in-Chief, Novosibirsk: CO RAN, 2017.

Translated by A. Petrosyan 